\title{
Illumination dangerous places on roads I. and II. classes in rural areas and urban interface
}

\begin{abstract}
Based on long-term cooperation with the Directorate of Traffic Police of the Czech Republic and the respective regional unions Traffic Police was elaborated plan instructional guidelines for traffic engineers Police. Within the traffic administrative proceeding was found many shortcomings in the lighting of roads especially in the submitted project documentation for traffic administrative proceedings etc.

I will deal with this issue and practical experience in my lecture including guidelines for cooperation and assistance of the Czech Society for lighting and Directorate of Traffic Police of the Czech Republic.
\end{abstract}

Keywords: Illumination dangerous places, road lighting

Úvod

Dlouhodobá spolupráce od roku 2009 s Policejním prezidiem ČR - Ředitelstvím služby dopravní policie začíná prínášet zkvalitnění posuzování nočního dopravního prostoru zejména prì nové výstavbě veřejného osvětlení na průjezdních komunikacích I.a II. tř́id městy a obcemi, včetně posuzování vhodnosti a kvality návrhu osvětlení nebezpečných míst, např́klad přechodů pro chodce okružních a průsečných křižovatek na rozhraní extravilánu a intravilánu.

Instrukčně metodická zaměstnání dopravních inženýrů jsou zaměřena na rozbor norem, technických předpisů , posuzování projektových dokumentací atd.

Pro Vaší představu Vás nejdřive seznámím s základní činností dopravních inženýrů policie ČR v tomto oboru a jak je jejich přínos v oblasti osvětlování pozemních komunikací prínosný.

> Dopravně inženýrský úsek služby dopravní policie ČR plní úkoly policie vyplývající z výkonu státní správy a prevence $v$ oblasti bezpečnosti a plynulosti provozu na pozemních komunikacích.

$>$ Vystupuje jako odborný orgán policie ve věcech majících vztah $\mathrm{k}$ bezpečnosti a plynulosti provozu na pozemních komunikacích, např. při řešení sítě pozemních komunikací, provozu na pozemních komunikacích, pripojování a dopravní obsluze objektů a řízení provozu na pozemních komunikacích.

> Vydává stanoviska $\mathrm{v}$ rámci územního a stavebního ř́izení $\mathrm{k}$ jednotlivým stupňům územní a projektové dokumentace pro novou výstavbu, změny užíání a stavební úpravy stávajících staveb, které zasahují do pozemních komunikací nebo se jich dotýkají, vyžadují dopravní obsluhu, dotýkají se pěší a cyklistické dopravy apod..

> Uplatňuje připomínky policie vưči orgánům státního stavebního odborného dozoru, investorům, zhotovitelům staveb a dalším subjektům ve vztahu $\mathrm{k}$ bezpečnosti a plynulosti provozu na pozemních komunikacích.

Z dlouhodobého školícího procesu jsme dopravním inženýrům policie ČR doporučili, aby se prì vyjadřovacím procesu dopravně správního rrízení zaměřili zejména na některé části PD $v$ oblasti osvětlování pozemních komunikací, zejména:

\section{Technickou zprávu PD}

Oblast zájmu posuzovaného textu v technické zprávě je zaměřen na: citace a odkazy na platné technické normy v oblasti osvětlování pozemních komunikací

> stanovení intenzity osvětlení řešeného prostoru , včetně světelné situace a uvedení světelně technických hodnot - parametrů pro navrhovaný prostor v návaznosti na navazují již existující osvětlené prostory.

\section{Světelně technické výpočty}

Oblast zájmu posuzovaného dokumentu je zaměřen na:

> Plánovací údaje - uvedení profilu komunikace , chodníků a identifikace řešeného místa. Stanovení činitele údržby , rozmístění svítidel soustavy VO (geometrie) a stanovení povrchu komunikace.

$>$ Světelně technické výsledky - soupis vyhodnocovacích polí jednotlivých řešených míst s uvedením zvolené třídy osvětlení, dále uvedením skutečných hodnot podle výpočtu a požadovaných hodnot dle zvolené třídy osvětlení.

> U přisvětlování přechodů pro chodce řešení výpočtem včetně zahrnutí celé soustavy VO v závislostech na adaptační zóny okolí přechodů pro chodce a přehledem výsledků výpočtu ve vertikální rovině přechodu pro chodce a nástupního prostoru.

Těchto pět bodi̊ pro posouzení kvality projektu je plně dostačující o čemž jsme se společně s dopravními inženýry přesvědčili a následně řešili.

Při posuzování projektové dokumentace v dopravně správním řízení se nejčastěji opakují tyto závažné nedostatky v PD:

\section{V technické zprávě schází :}

> Absence stanovení světelné situace dle (ČSN CEN/TR 13201-1) na základě členění funkčních tříd komunikací podle struktury osídlení , dopravního významu a vazby na komunikace ve volné krajině (ČSN EN 736110) .

> Absence definování třídy osvětlení dle (ČSN EN 13201-2) soustavy fotometrických požadavků , sledujících zrakové požadavky daných uživatelů , pro určitý typ pozemních komunikací a prostředí. 
Technické zprávy řeší v plné míre elektrickou část projektu, částí světelně technické se zabývají jen částečně nebo vůbec. Př́ičina je asi v tom, že většina projektantů elektro projektuje VO jen okrajově. Projektanti VO nemají ve většině prípadech základní znalosti 0 světle, což se potvrdilo i na jednáních mezi DI PČR a projektantem, kde nám bylo sděleno projektantem, že neví jak to má svítit (jsem projektant elektro - nevím co po mně chcete). Některé projektové dokumentace byli vráceny k přepracování a doplnění i několika násobně.

Když se ohlédnu zpětně tak musím konstatovat, že asi největší chybou je zadání investora co vlastně chce, zejména u menších měst a obcí, v některých prípadech bohužel i velkých měst. $Z$ dohledávaní dat o řešených komunikacích Ize vyvodit:

> Že ne všechny města a obce vlastní aktuální pasport komunikací

> Když není pasport komunikací nelze stanovit světelnou třídu ani hladinu osvětlení, je to velice těžké a je to vidět $v$ terénu kdy každý projektant tyto parametry stanovuje individuálně bez jakkoliv logicky navazujících hladin osvětlení dopravního prostoru.

Tak, že máme místa s velkou intenzitou osvětlení, která navazují na velice nízkou hladinu osvětlení atd. Tento způsob řešení pak vytvárí nepřirozené prostředí a zpětně z vyhodnocení dopravní nehodovosti jednoznačně prokazuje zvýšení DN v úsecích tak to řešeného osvětlení.

\section{Výpočet osvětlení}

$>$ Výpočty jsou prováděny $\mathrm{v}$ nevhodných programech tak, že komunikaci počítáme například v místnosti.

> Výsledky výpočtu osvětlení na základě daných parametrů pro třídy ME jsou uváděny v luxech.

> Ve většině případech schází geometrie soustavy VO a řešeného prostoru (plánovací údaje) tak, že není možné posoudit co bylo vlastně počítáno.

> Součástí výstupu výpočtu osvětlení není výpis stanovení třídy osvětlení v závislosti na provozní situaci.

Je zbytečné se $\mathrm{k}$ tomuto dále vyjadřovat sami vidíte, že dopravní inženýři to nemají lehké a projektanti jim to nezjednodušují. Dalším problémem je, když se do řešení zapletou politici , to je kapitola sama pro sebe a na další přednášku.

Př́klady nevhodného řešení jsou rozděleny do dvou oblastí:

\section{Politická rozhodnutí}

Zrízení bezpečného přechodu pro chodce na mezinárodní komunikaci E65 I/10. Nevhodná rekonstrukce VO v centru města (intenzita osvětlení komunikace je o dvě třídy nižší), včetně zríizení dvou přechodů 3 generace. Dopravní stavba roku v LK. Do dnešního dne není tato stavba zkolaudována. Výsledkem nevhodné realizace je rapidní nárůst dopravní nehodovosti v noci včetně 2 mrtvých osob do $20 \mathrm{~m}$ v okolí přechodu pro chodce. V současné době probíhá řešení a zjednání nápravy . Stavba byla financována $z$ dotačního titulu tak, že 5 let se s tím nedalo nic dělat. Viz fotodokumentace dopravního prostoru.
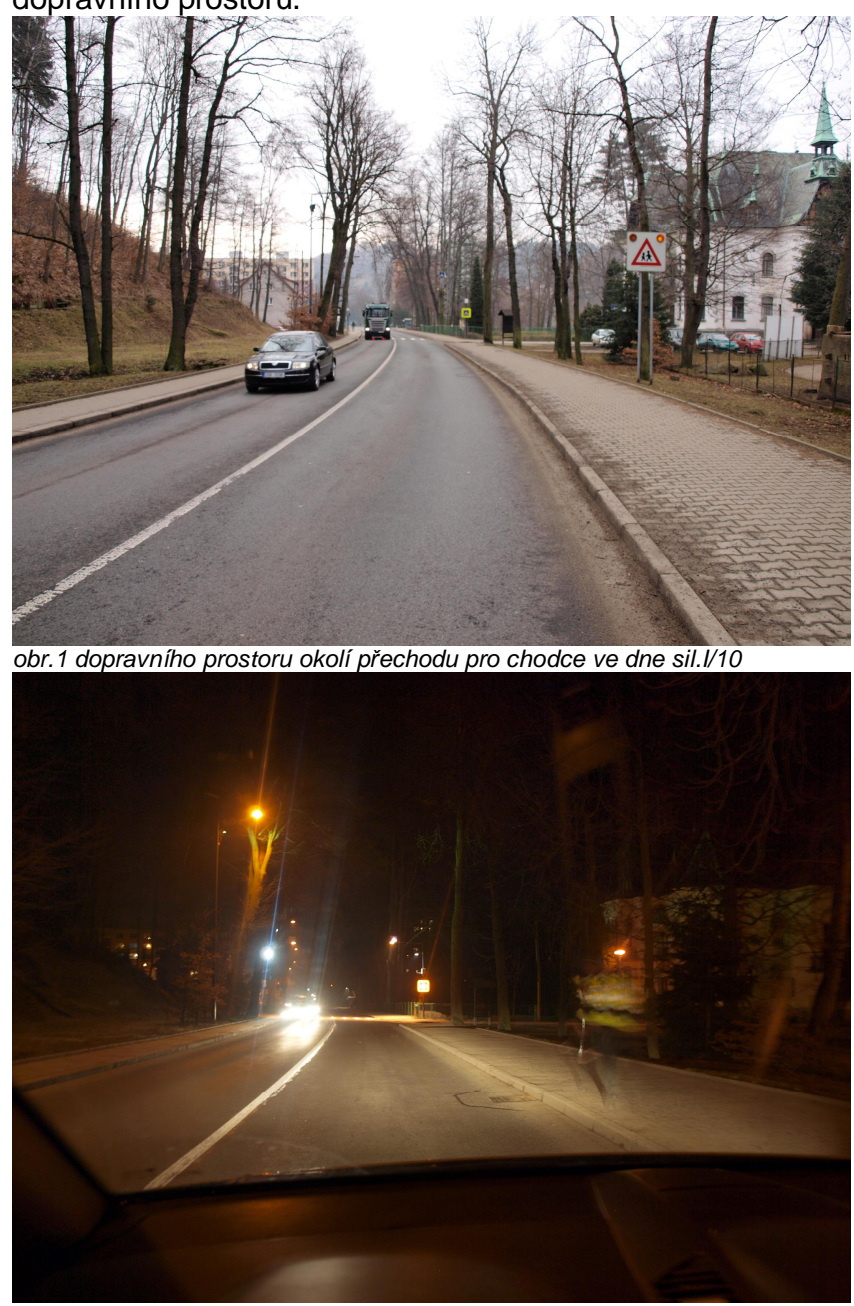

obr.2 dopravního prostoru okolí prechodu pro chodce $v$ noci sil.l/10

Osvětlení přechodů pro chodce na komunikaci II/592 přes odpor správce VO, města jako vlastníka VO a policie ČR si vlastník komunikace - kraj prosadil své tak, že máme oboustranně osvětlené přechody v jednosměrné komunikaci. Financováno z dotačního titulu, v současné době je jedno svítidlo vypnuto a 5 let se na to budeme dívat pak se to zruší.

Rekonstrukce veřejného osvětlení včetně chodníků na komunikaci $\mathbf{1} / \mathbf{3 8}$. Staré výbojové osvětlení které splňovalo veškeré požadavky na osvětlení průjezdné komunikace obcí bylo nahrazeno novým led osvětlením. Pro porovnání 150W sodíkové výbojky bylo nahrazeno 40W led svítidlem. Výsledek je katastrofální rovnoměrnost osvětlení a intenzita osvětlení odpovídá parku poprípadě osvětlení prostorů s minimálním zrakovým úkonem. Viz noční fotografie. Celý projekt byl financován z dotačního titulu. 

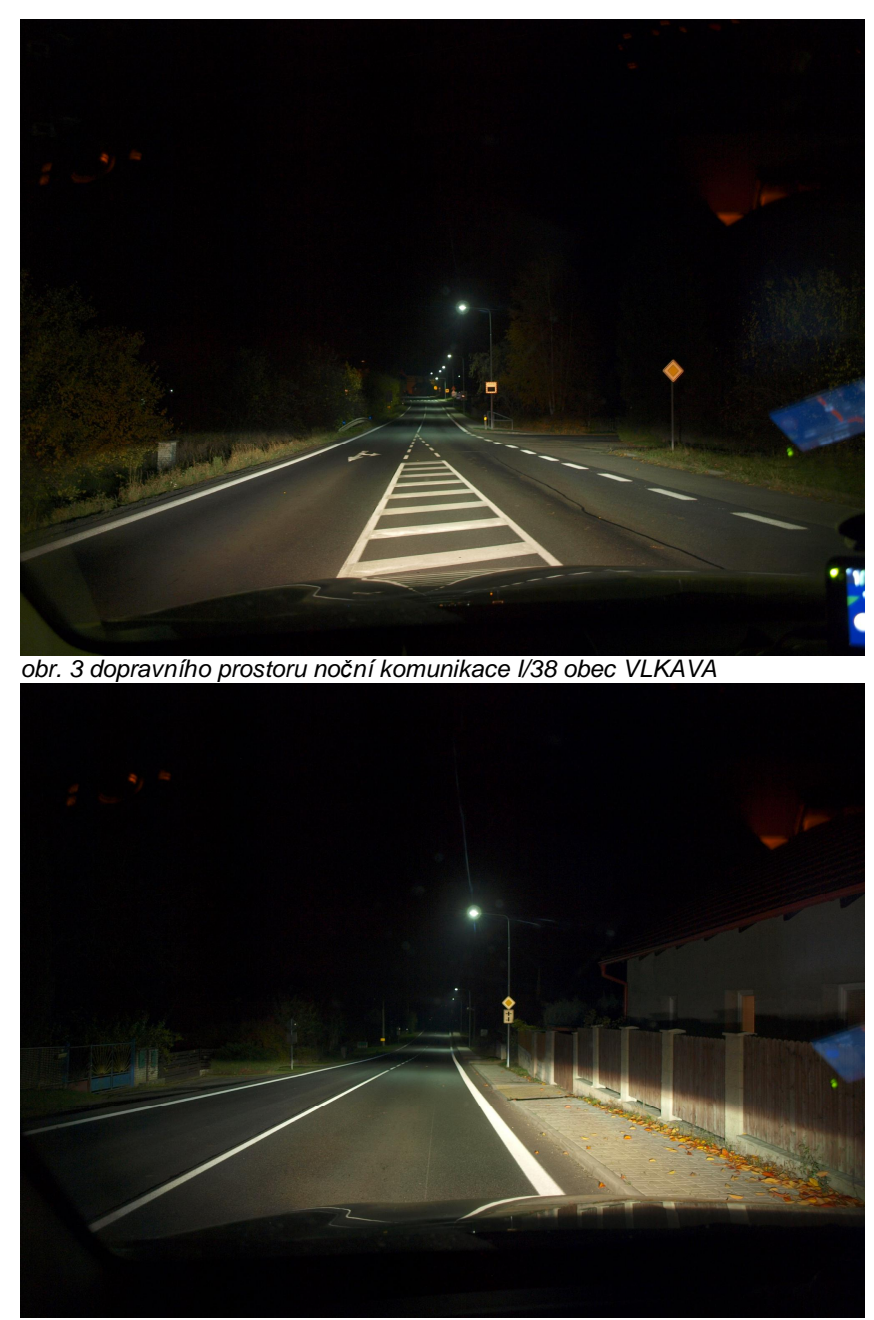

obr. 4 dopravního prostoru noční komunikace I/38 obec VLKAVA

\section{Požadavky - zadání vlastníka komunikace ŘSD - kraj - obec.}

Komunikace I/13 centrum obce. Obec požádala vlastníka komunikace o zřízení přechodu pro chodce. Vlastník komunikace požaduje tento přechod přisvětlit. Projektant tento problém řešil bez vazby na stávající osvětlení obce. Navrhl osvětlení přechodu v proluce bez stávajícího osvětlení a napojil ho na rozvod el.energie v hasičské zbrojnici. Neřešil adaptační zónu ani nerespektoval provoz stávající soustavy VO, která je od 00,00 hod mimo provoz. Přechod měl svítit trvale v nočních hodinách kde jsou velice nízké jasy okolí. V současné době probíhá řešení změny $P D$, na kterou bylo již vydané stavební povolení a schválená dotace ze Státního fondu dopravní infrastruktury. Nevhodnost tohoto řešení je patrné z pořízené noční fotodokumentace dopravního prostoru.
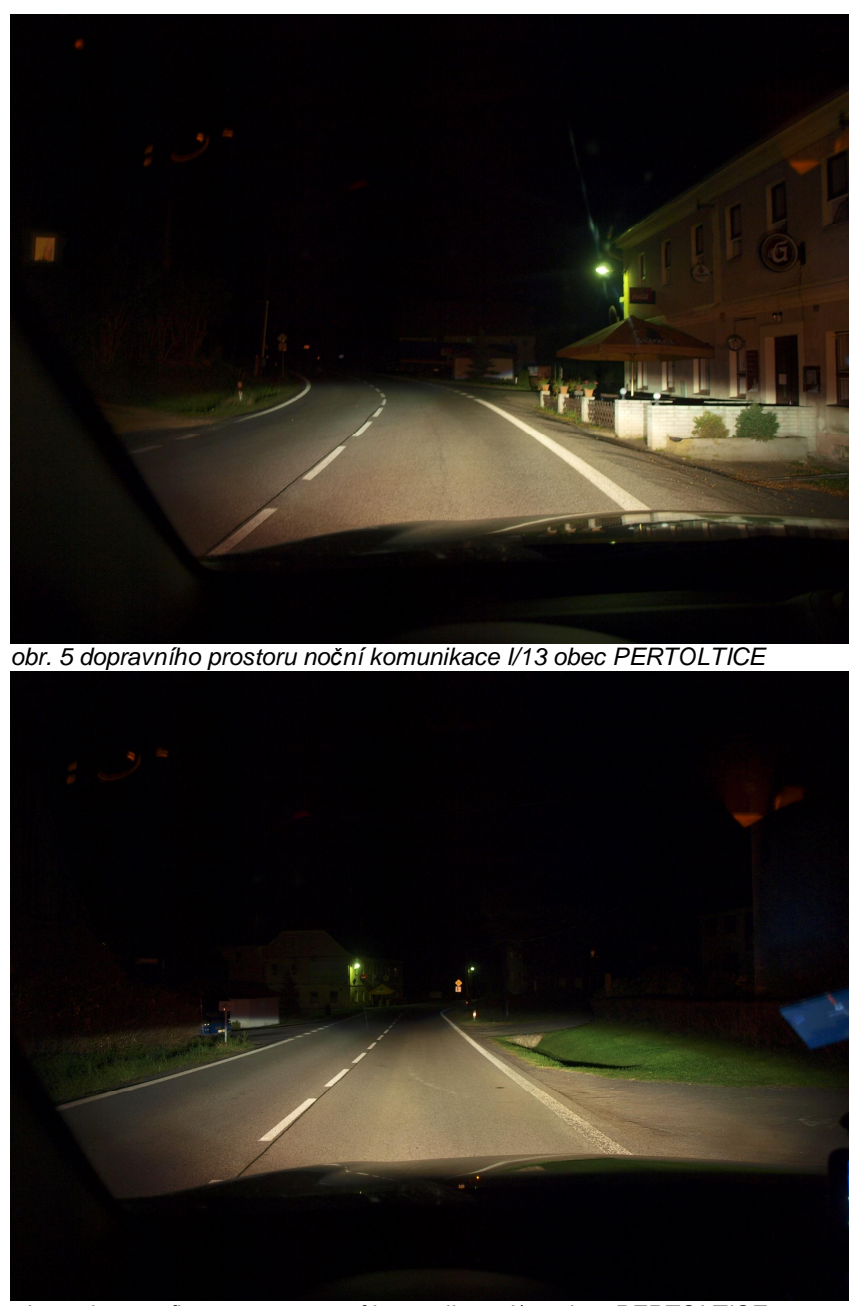

obr. 6 dopravního prostoru noční komunikace I/13 obec PERTOLTICE

Komunikace E442 I/35 nájezdová rampa. Projektant řešil VO na nájezdové rampě velice nezvyklým způsobem kde zejména řešil požadavek Českých drah, aby neoslňoval strojvůdce souběžné železniční tratě. Způsob oslnění rìdičů na komunikaci s průjezdností 40.000 vozidel neřešil. Dalším problémem je, že nájezdová rampa počítá s rychlostí 70 $\mathrm{km} /$ hod a v místě napojení $90 \mathrm{~km} / \mathrm{hod}$. Projektant navrhl hladinu osvětlení v třídě S4 bez zdůvodnění. Vlastník VO vydal souhlasné stanovisko za předpokladu splnění jednotlivých podmínek bez stanovení požadované hladiny osvětlení řešeného úseku. $V$ současné době probíhá řešení změny PD. Úsměvný př́klad výpis z předložené PD.

\subsection{Určení úrovně osvětlení: určeni barvy světla}

Projekt se týká pouze malého úseku komunikace a pouze jednoho z mnoha míst pro preccházen $Z$ těchto dũvodủ bude osvẽtlení respektive prisvěttlení rešeno stejným zpủsobem, jako stávajic osvětlení respektive prisvětlení v okoli.

Ulice Obchodní je osvětlena ve stupni III dle ČSN 360410 z 1.10.1985; stejným zpủsobem bude osvětlena i nájezdová rampa Turnov (jas povrch $0,4 \mathrm{~cd} / \mathrm{m} 2$ nebo více, celková rovnomërnost 40 až $100 \%$, podélná rovnomérnost 50 až $100 \%$ ).

Mista pro přecházení jsou v místě stavby prisvětlena svítidly $s$ odlišnou barvou světla, aby projektované místo pro precházení v protikladu proti ostatním místủm pro precházeni v okol nezaniklo $v$ nenápadnosti, bude rovněž osvètleno $s$ odlišnou barvou světla. $V$ době výstavby stavajiciciho verejneho osvetteni pro prissvětlení míst pro precházeni nebyl żádný předpis, $\checkmark$ současné dobé pro prisseětlení prechodú pro chodce platí TKP 15 dodatek č. 1 tabulka 1 , pro ulice do $0.5 \mathrm{~cd} / \mathrm{m} 2$ (rampa Turnov) predepsaná prủměrná SVISLÁ osvětlenost na vozovce v misté přecházení 15 až 50 luxủ, do hloubky 1 metr na chodnicích pr̆lehlých k místu přecházeni 10 až 50 luxủ.

Výřez částí technické zprávy $P D$

Komunikace $\mathrm{I} / 10$ extravilán osvětlení přechodu pro chodce na okružní. Velice nebezpečné místo na rovném úseku za horizontem. Osvětlení přechodu a osvětlení průmyslového areálu vytvárí pro řidiče v nočním prostředí nebo za snížené viditelnosti předpoklad rovného úseku bez překážky na vozovce. Bohužel v tomto prrípadě je okružní křižovatka tvořena vnitřním zvýšeným kamenným rondem, 
které vytváří nebezpečnou překážu na vozovce. Od doby realizace zde byl $v$ noční době jeden smrtelný úraz a 5 těžce zraněných (vždy narazili do ronda).V současné době probíhá řešení úpravy osvětlení prostoru OK.

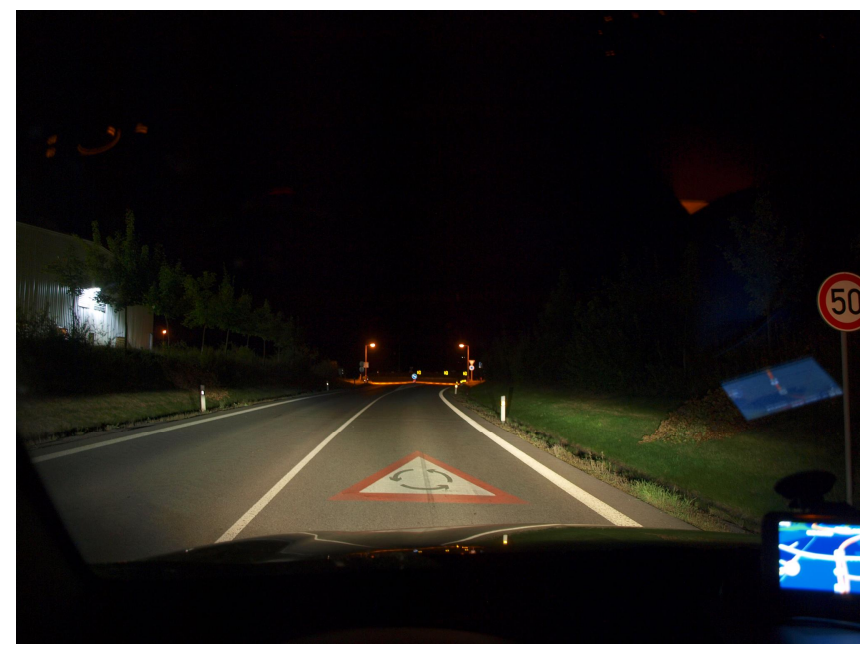

obr. 7 dopravního prostoru noční komunikace I/14 obec Turnov-Vesecko

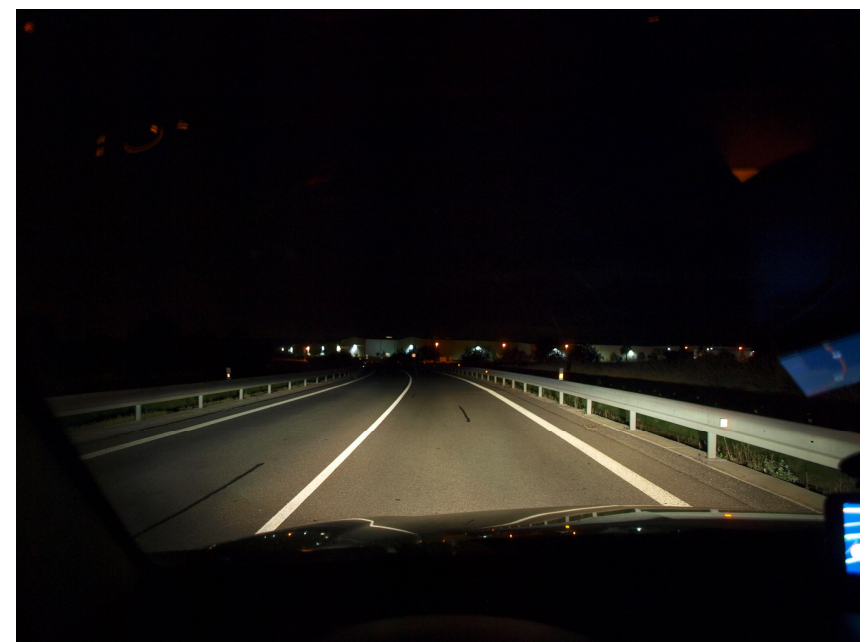

obr. 8 dopravního prostoru noční komunikace l/14 obec Turnov-Vesecko

Řešení osvětlení okružní křižovatky na komunikaci I/35 v extravilánu, která byla podobně osvětlena jako předešlá OK na $\mathbf{I} / \mathbf{1 0}$. Tato $O K$ byla dopravní policí vyhodnocena jako velice nebezpečná $s$ velkou četností dopravních nehod. Po dohodě policie ČR , RSS oblast Liberec a městem Hrádek nad Nisou byla provedena realizace osvětlení $O K$, včetně demontáže osvětlení prechodu III. generace, led diod v komunikaci atd. Výsledek viz foto níže.

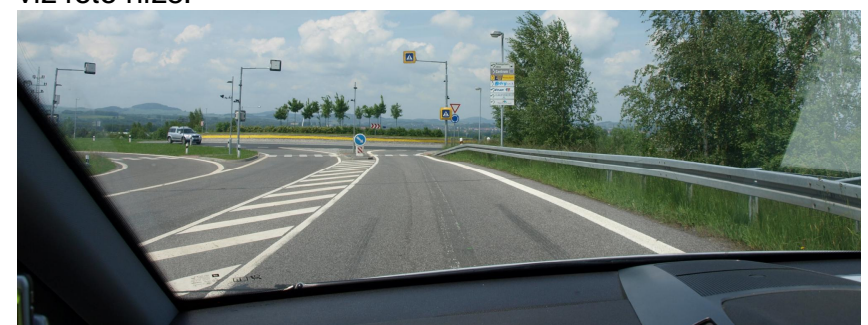

obr. 9 dopravního prostoru denní komunikace OK I/35 obec Hrádek n.Nisou, pred rekonstrukcí VO.

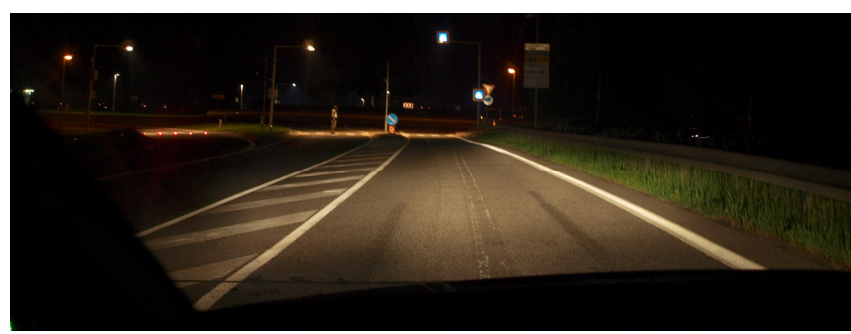

obr.10 dopravního prostoru noční komunikace OK l/35 obec Hrádek n.Nisou, pred rekonstrukcí VO.

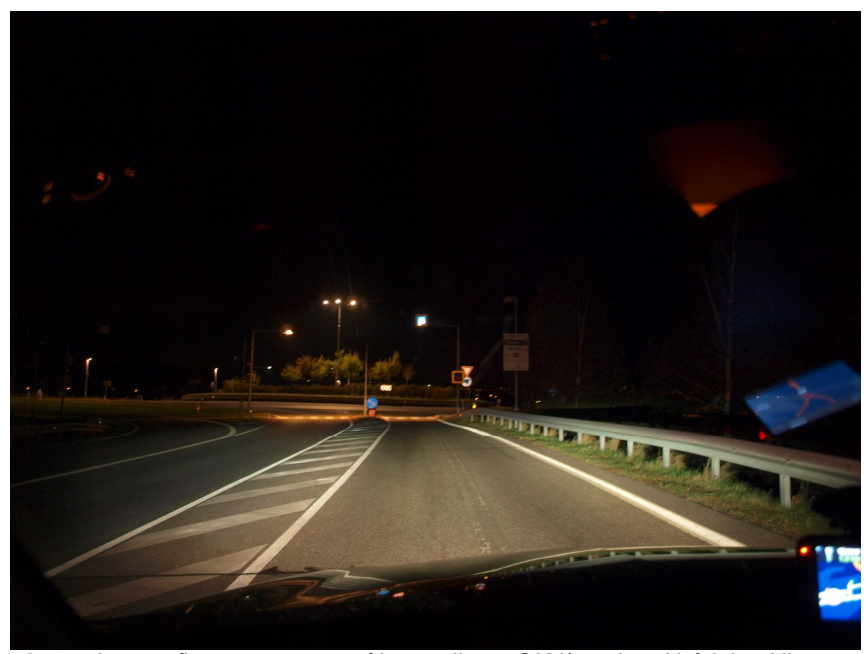

obr.11 dopravního prostoru noční komunikace OK I/35 obec Hrádek n.Nisou, po rekonstrukcí VO.

Realizace byla provedena v září roku 2014 do dnešního dne zde nebyla žádná dopravní nehoda v noční době.

Dalo by se popsat mnoho dalších príkladů, určitě by to vydalo na několik stran textu, možná celý sborník, to je ale zbytečné.

\section{Závěr}

Za kvalitu projektu odpovídá projektant tak, že i za část kvality osvětlení a následné škody. Projekt VO je sice projektem elektro, ale hlavně projektem osvětlení. Pracovníci ve schvalovacím procesu státních orgánů nejsou specialisty na jednotlivé profese, kontrolují jen formální stránku projektů. Po realizaci se velice těžko odstraňují případné vady špatné PD. Specialista $s$ autorizací každý svůj projekt označí razítkem a podpisem, pro státního úředníka by to měla být záruka kvalitně zpracované dokumentace. Bohužel to ,ale v mnoha případech neplatí.

Jsem velice rád, že naše přednášky pro dopravní inženýry policie ČR padly na úrodnou půdu a díky jejich důkladnosti jsme schopni některé projekty usměrnit do patřičných mezí tak, aby splňovali aspoň základní požadavky technických norem.

Dopravní inženýr policie ČR a referent dopravně správního úřadu není autorizovaný projektant. Jejich úkolem není posuzovat technickou kvalitu projektu, ale vydat stanovisko - rozhodnutí v jednotlivých stupních stavebního rízení. Garancí správně provedeného projektu veřejného osvětlení je vždy autorizovaný projektant .

\section{A na úplný závěr - pro bezpečně osvětlené noční komunikace}

1. Každé experimentování se světlem bez odborného dohledu světelného technika na pozemních 
komunikacích, nebo v jejich blízkosti je hazardování s lidským životem.

2. Veškeré změny $v$ osvětlování dopravního prostoru by měly být předem vypočteny - respektive navrženy tak, aby splňovaly základní požadavky norem a technických předpisů.

3. Není světlo jako světlo - zástupci samosprávy (vlastnící VO) by neměli podlehnout tlakům obchodních firem, které nabízí velké úspory ve spotřebované el.energii , údržbě atd.

4. Osvětlování přechodů pro chodce není všelék na snížení DN. Je to jen jedno z mnoha opatření. Při špatné instalaci použití nevhodných svítidel světelných zdrojů může být toto řešení kontraproduktivní.
5. Světelné diody v přechodu pro chodce nemají co dělat, odpoutávají pozornost rìdiče zejména $\mathrm{v}$ noci (oslňují, oko vnímá prechod a ne okolí).

\section{Literatura a odkazy}

[1] (ČSN CEN/TR 13201-1, ČSN EN 13201-2)

[2] (ČSN EN 736110)

[3] (pplk.Judr. Sabina Burdová, rada Policejního prezidia Reditelství služby dopravní policie)

[4] ( Jiř́ Tesař, ČSO regionální skupina Labsko Vltavská - soubor přednášek IMZ dopravní policie ČR)

[5] Obr. 1 až 11 archiv autora

Author: Jiří Tesař, Česká společnost pro osvětlování - regionální skupina Labsko Vltavská, Janáčkova 217/11, 46606 Jablonec nad Nisou, Czech Republic, e-mail: jiri.tesar@artmetal-cz.com 